Article

\title{
Sustainability Managed against Downside Risk and the Cost of Equity: Evidence in Korea
}

\author{
Truong Thi Thu Thuy and Jungmu Kim *(D) \\ Department of Business Administration, School of Business, Yeungnam University, Gyeongsan 38541, Korea; \\ thuytruong@ynu.ac.kr \\ * Correspondence: jungmu@yu.ac.kr; Tel.: +82-53-810-2843
}

Received: 2 October 2018; Accepted: 26 October 2018; Published: 31 October 2018

\begin{abstract}
This study examines the relationship between sustainability managed against downside risk and the cost of equity in the Korean stock market during the 2000-2016 period. We employ downside co-skewness and downside beta as a measure of downside risk, to analyze the cross-sectional relationship between them and average portfolio stock returns. We have also carried out Fama-MacBeth regressions to find the required return for bearing downside risk. The results show that downside co-skewness can be used more effectively than downside beta to explain a cross-section of stock returns or cost of equity. The required premium for bearing downside risk, as measured by downside co-skewness, is approximately $19 \%$ per annum in the Korean stock market. This finding suggests that sustainable companies can raise their capital in the form of equity at $19 \%$ lower costs, and also implies that increasing sustainability can reduce the cost of capital.
\end{abstract}

Keywords: cost of capital; downside risk; Korean stock market; vulnerability; sustainable business

\section{Introduction}

Emerging stock markets are vulnerable to market downside risk compared to developed countries. Emerging market economies suffered from the Asian financial crisis in 1997. The U.S. subprime loan defaults transmitted the crisis to emerging markets during the 2008 global financial crisis. The 2009 Greek debt crisis also affected emerging stock markets. Recently, the ongoing 2018 China-United States trade war has been crashing emerging markets. As such, the management of sustainability against downside risk is of importance, particularly to companies in emerging markets.

The Korean stock market can be a good venue to study the effect of sustainability managed against downside risk on the cost of equity. Korea is a leader among emerging markets in terms of GDP per capita (US\$29,742.84 in 2017). The market capitalization of listed companies in the Korea Exchange is relatively high (US\$1,771,763.93 million), compared to other emerging markets, such as Argentina (US\$108,740.05 million), Brazil (US\$954,715.10 million), Indonesia (US\$520,686.68 million), Malaysia (US\$455,772.49 million), and Thailand (US\$548,795.41 million).

The classification is different depending on analyst groups, the MSCI Emerging Markets Index includes Korea and the IMF classifies Korea as a developed market. Moreover, Korea has focused on promoting corporate sustainability to encourage sustainable development. In 2015, the Korea Exchange joined the United Nations Sustainable Stock Exchanges initiative. Therefore, we can regard the Korean stock market as a representative of emerging markets. For these reasons, we analyze the effect of sustainability managed against downside risk on the cost of equity in Korea.

Downside risk is typically defined as the potential loss of the value of a stock in a declining market [1-3]. Recent studies have argued that downside risk must be taken into account in asset pricing because investors are more concerned about losses in declining markets than gains in rising markets (see, e.g., [4,5]). The implication of loss aversion preferences used by Kahneman and Tversky [6] is 
that investors are more sensitive towards downside risk. It has also been argued that "losses and disadvantages have greater impact on preferences than gains and advantages" [7]. Investors are more reluctant to invest in companies whose performance is more vulnerable to economic declines, recessions and crises, even if the companies can earn higher cash flows in times of economic booms. By contrast, investors generally prefer investing in companies operating sustainable businesses and earning robust cash flows. As a result, expected stock returns on the vulnerable firms are higher and the cost of capital (or internal rate of stock return) is lower for firms with higher sustainability.

In this study, using downside risk measures we estimate the vulnerability (or the opposite to sustainability) perceived by stock investors. If a firm's earnings are more vulnerable to economic crashes, the downside risk estimate for the firm would be higher. We can then examine whether the higher sustainability can reduce the cost of capital by testing the cross-sectional relation between downside risk measures and future stock returns.

Recently, downside risk measures have received extensive attention in the finance literature. Theoretical papers, such as $[1,8,9]$, prove that the market downside factor is also priced, in addition to the market beta. Intuitively, stocks that are more sensitive to market risk when the market declines or are less sustainable against downside risk tend to incur larger losses in declining markets and are not attractive to hold. For this reason, investors require higher compensation to hold such stocks or those stocks have a larger cost of equity. In other words, a positive premium for downside risk is required in the stock market. Several studies have suggested measures of downside risk, such as $[1,9,10]$, which have used downside beta as a measure of downside risk in U.S. stock returns. However, Galagedera and Brooks [11,12] have suggested that another downside risk measure can explain the cross-section of returns, namely downside co-skewness. The present study has used both downside co-skewness and downside beta as measures of downside risk, comparing their explanatory power in cross-sectional stock returns in the Korean market. To the best of our knowledge, the Korean stock market as a leading market among emerging markets remains an open question in examining whether downside risk is a priced factor in stock returns or not.

The downside risk of the Korean stock market is worth examining for several reasons. First, as Bekaert et al. [13] have argued, the return distributions of emerging markets have very different characteristics from those of developed markets. Stock returns in emerging markets are more asymmetric and skewed. Galagedera and Brooks [11,12] have shown that the distribution of stock returns in Korea is positively skewed. Since investors care more about downside losses, higher asymmetry and skewness are likely to have more influence on a premium on the downside risk in any direction. It is therefore important to study how the downside risk is priced in Korea, a leading market among emerging countries.

Second, as described in the following literature review, while the downside risk premium is known to be positive in empirical studies of developed markets, the results are inconclusive and inconsistent in emerging markets. It is likely to be positive $[10,14]$ or insignificant [15]. Thus, the Korean market can be analyzed as an out-of-sample test.

Our empirical methodology and findings are summarized below. First, we examined the contemporaneous relationship between average returns and downside risk measures. Portfolios were formed by sorting stocks, based on the traditional risk measure of capital asset pricing model (CAPM) beta and downside risk measures, such as downside co-skewness and downside beta. The results suggest that sorting stocks based on downside co-skewness results in a more significant cross-sectional spread in average returns than sorting stocks based on other risk measures. In other words, downside co-skewness is more appropriate for explaining the spread of average returns than downside beta or regular beta (CAPM beta). The results also show that portfolios with high (low) downside co-skewness earn high (low) average stock returns over the same period.

Second, according to the results of a correlation analysis, these risk measures are highly correlated. When we disentangle the different effects of downside co-skewness from other risk measures, using double-sorted portfolios, the results suggest that the high returns of high downside co-skewness are controlled for regular beta or downside beta. 
Finally, we examine the explanatory power of downside risk measures and find the premium for downside risk, controlling for other cross-sectional effects simultaneously by using Fama-MacBeth regressions [16]. The results further confirm that downside co-skewness is more appropriate than other measures for use in the Korean market. When regular and downside beta are included, along with downside co-skewness in regressions, only the premium for downside co-skewness turns out to be significant. The premium for downside risk is approximately $19 \%$ per annum and statistically significant, after controlling for other cross-sectional effects.

The empirical results of our research confirm the role of downside risk in explaining cross-sectional returns and in reducing the cost of capital. We find that investors request a $19 \%$ more premium per annum for more vulnerable firms. In other words, more sustainable firms can finance their capital in the form of equity at $19 \%$ lower costs. Therefore, it is important for firms who want to reduce their cost of capital to increase sustainability in their cash flows (i.e., to decrease downside risk).

The remainder of this study is structured as follows. Section 2 reviews previous literature on downside risk. Section 3 describes the data and illustrates the method used to measure downside risk; it also develops a downside risk-based portfolio to examine the cross-sectional relationship between returns and downside risk measures. In addition, Fama-MacBeth regressions have been carried out to identify the reward for downside risk, controlling for other cross-sectional effects. The results of the analysis of portfolios and Fama-MacBeth regressions are interpreted and discussed in Section 4. Finally, Section 5 concludes this research.

\section{Literature Review}

Research on issues and strategies relevant to sustainable development not only in the environmental area but also in the economic and social areas has become more prominent in recent days in Korea [17-20]. At the individual firm level, the definition of corporate sustainability has been defined by Dyllick and Hockerts [21]. Schaltegger et al. [22] have determined that corporate sustainability management is proposed to control the environmental, social, and economic effects of a company, first resulting in the company's sustainable development and then contributing significantly to the sustainable development of the economy and society. Sustainable companies are committed to a set of goals to protect against downside risk [23,24], thereby reducing the cost of equity.

The relationship between corporate sustainability and cost of equity has been of interest in recent research. For example, $\mathrm{Ng}$ and Rezaee [25] examined the effect of business sustainability performance on cost of equity with sample of U.S. firms between 1991 and 2013. They found that two dimensions of sustainability (i.e., financial and non-financial performance) are negatively associated with cost of equity. In other words, the firms with stronger sustainability performance or less vulnerable to downside economic risk tend to have a lower cost of equity. Lourenço and Branco [26] analyzed the determinants of corporate sustainability performance with a sample of Brazilian companies available at the end of 2010 and suggested that leading sustainability performance firms are significantly larger and have a higher equity return than their counterparts. Sharfman and Fernando [27] found a negative relation between environmental risk management and cost of equity by using data of U.S. companies and cost of equity calculated from CAPM. El Ghoul et al. [28] provided similar results for a large sample of U.S. firms from 1992 to 2007 and confirmed that firms with better CSR (corporate social responsibility) performance rankings have a lower cost of equity. Specifically, they suggested that investment in employee relations and environment protection help to reduce firms' cost of equity. Furthermore, after controlling the firm's CSR performance, Dhaliwal et al. [29] showed that CSR disclosure is negatively related to the cost of equity for a sample of large U.S. companies from 1993 to 2007. Using an international sample of 42 countries from 2002 to 2013, Matthiesen and Salzmann [30] also concluded that the more companies involved in CSR, the lower the cost of equity. Some other recent papers have also proved a significantly negative relationship between CSR disclosure and cost of equity capital (see, e.g., [31-34]). Based on the suggestions of previous studies, this study examines 
whether higher sustainability leads to lower cost of equity by testing the relation between downside risk measures and stock returns.

Several studies have demonstrated the importance of downside risk measures in asset pricing. For example, in an extended sample (1926-2002), Post and Van Vliet [35] argued that downside beta is better at explaining U.S. stock returns than regular beta. Ang et al. [1] analyzed the sample from July 1962 to December 2001 and confirmed that downside beta has higher explanatory power in U.S. stock returns than regular beta. More importantly, they showed that the cross-sectional premium for bearing the downside risk measured by downside beta in the U.S. stock market is approximately $6 \%$ per annum, after controlling for the cross-sectional effects of other firm characteristics, such as the size, book-to-market, and momentum effects—and also risk effects, such as volatility, co-skewness, co-kurtosis, and liquidity risk. Post and Van Vliet [9] also suggested that the downside beta explains the cross-sectional variation of stock returns better than the CAPM beta in the U.S. stock market within the sample period from 1933 to 2002. Chen et al. [8] used traditional and downside risk measures to examine their explanatory power for NYSE stocks from January 1981 to December 2002. They concluded that downside risk measures provide a better measure of risk than traditional risk measures.

In emerging markets, Estrada [10] analyzed data on 27 emerging markets for sample periods from 1988 to 2001, and suggested that returns are more sensitive to differences in downside beta than regular beta. Downside risk measures have explanatory power in the relationship between risk and returns. Estrada [36] also supported his previous study that downside risk measures perform better for emerging markets with skewed distribution of returns. Alles and Murray [15] demonstrated the cross-sectional relationship between downside risk measures and average stock returns in emerging Asian markets over the 10-year period from June 1999 to May 2009. Unlike previous studies, they split the whole sample into two subsamples, consisting of observations in the downturn and upturn periods. In the downturn (upturn) period, market returns were below (above) the risk-free rate. In both periods, all downside risk measures were priced. In the upturn (downturn) period, they found that the risk premium for downside beta was approximately $13.3 \%(-14.9 \%)$ per annum. When the upturn and downturn were combined, this premium became insignificant. In a specific emerging market, such as Pakistan, Rashid and Hamid [14] tested the downside risk CAPM introduced by Estrada, Bawa and Lindenberg, Harlow and Rao [10,37,38] in a Fama-MacBeth two-stage regression [16] for the period from January 2000 to December 2012, in order to ascertain which downside measures were better at measuring downside risk in relation to stock returns. They observed the relationship between risk measures and returns over each 5-year period, with an overlapping sub-period, to evaluate the time-varying effects of risk measures on stock returns. They suggested that the premiums for downside beta are positive and consistent with theory. Although most of the estimates over each period appear statistically insignificant, the version of downside beta offered by Bawa and Lindenberg [37] is more suitable than the other two versions of downside beta. Analyzing the UK market from August 1991 to July 2001, Pedersen and Hwang [39] showed that downside beta is the limited use of asset pricing. They examined whether downside beta is priced in asset pricing by determining how many individual stocks are priced better by downside beta than by conventional CAPM. The results show that, although downside beta is better for asset pricing than conventional CAPM, only $75-80 \%$ of stocks can be explained by downside beta. This may not be a large enough proportion to explain the cross-section of expected returns. In summary, downside risk measures have more explanatory power than traditional risk measures.

Downside beta is a common measure used by researchers in downside risk measurement. However, according to Pedersen and Hwang [39], downside beta is not an appropriate measure of downside risk in all markets. Many researchers have suggested another measure of downside risk, namely downside co-skewness. For example, in the U.S. stock market for the sample period from July 1963 to December 1993, Harvey and Siddique [40] observed that conditional co-skewness explains the cross-sectional variation in expected returns and conditional co-skewness captures 
asymmetry in risk, in particular downside risk. Galagedera and Brooks [11] demonstrated that downside co-skewness is better at explaining the cross-section of returns in 27 emerging markets than downside beta with sample periods beginning in December 1987 or December 1992 through December 2004. Galagedera [12] examined downside risk measures in a cross-sectional relation to excess returns in both developed and emerging markets. The data for emerging markets started from January 1993 to June 2006 and for developed markets from January 1970 to June 2006. It used both downside beta and downside co-skewness as measures of downside risk. The author suggests that, in developed markets, neither measure of downside risk is better than CAPM beta. By contrast, in emerging markets, downside co-skewness explains stock returns better than either downside beta or CAPM beta. Thus, downside co-skewness and downside beta are both used as measures of downside risk in the present study. Our research differs from previous studies in basing downside co-skewness on the measure of systematic co-skewness risk proposed by Ang et al. [1], rather than the measure of systematic co-skewness risk proposed by Kraus and Litzenberger [41] in previous studies.

Based on this stream of literature, downside risk can be priced in asset pricing. As noted, previous studies have suggested using downside risk measures rather than unconditional beta (CAPM beta). Although previous researchers have demonstrated the importance of downside risk measures, namely downside co-skewness and downside beta, in stock market asset pricing, none have focused on Korean stock returns. Thus, our research makes a valuable contribution to the literature by examining whether the downside risk premium of Korean stock returns is significant or not, as well as whether stock returns sorted in accordance with downside risk conform to the same pattern observed in the US stock market-and which downside risk measure is most appropriate for the Korean stock market. Moreover, this study contributes to the literature on the sustainability and the cost of capital. Economic sustainability has been studied on the aggregate level [42,43]. Such papers implies that managing economic risk is essential to ensure sustainable economic growth. Our research focuses on individual sustainability at the firm level. With a notion that more sustainable firms have lower downside risk, we estimate the individual sustainability of a business and examine its relation with the cost of equity. Our paper also contributes to previous studies on the relation between corporate sustainability and the cost of equity capital. Consistent with the findings of previous studies, such as $[25,28]$, we find a negative relation and provide additional evidence about the asymmetric relation; i.e., if a firm is more vulnerable to downside economic risk, the cost of equity capital is higher.

\section{Data and Methodology}

\subsection{Data}

This research incorporated all the Korea Composite Stock Price Index (KOSPI) stock data from DataGuide. The sample period for the daily and monthly data ran from 4 January 2000 to 29 December 2016. The average number of stocks in the market over the sample periods was 963 . To calculate excess returns, we choose the certificate of deposit 91 day (CD-91) rate as the risk-free rate and calculated the simple holding period return using stock dividend-adjusted price data.

The proxy used for the market return was the KOSPI index, available on DataGuide. We also used the accounting information found on DataGuide. In calculating independent variables, we required a stock to have at least 120 days of data available for a 12-month period. Observations that did not satisfy the above condition were excluded from the sample. We also "Winsorized" all independent variables in the Fama-MacBeth regression at the 1\% and 9\% levels to minimize the effect of outliers.

\subsection{Downside Risk Measures}

Our central interest of the empirical methodology lies in how to define and measure the firm-specific sustainability to market downside risk. First, we define that a firm is vulnerable to downside risk when the firm's equity value significantly co-moves with the market downside movements. Oppositely, if the sensitivity of equity value to market downside movements is low, 
the firm can be regarded as a sustainable firm. Thus, with our definition, sustainable firms' equity value is not influenced much by the market drops.

With this definition, we propose two empirical methodologies to estimate the sustainability to downside risk for individual firms, providing the details on the estimation in the following subsections. Roughly speaking, we compute the sensitivity of equity value to market return (downside beta) or to squared market return (downside co-skewness) during market downturn periods. According to our definition, if a firm is sustainable to downside risk, then the firm's equity value is less sensitive to market conditions during downside periods. Since the sustainability measures quantify the sensitivity to downside movements, firms with lower values of the measures are regarded as more sustainable firms.

\subsubsection{Downside Co-Skewness}

Downside co-skewness $\left(\mathrm{Coksew}^{-}\right)$uses a similar calculation to co-skewness [1]; the difference is that the whole sample is divided into two periods, the downside and upside periods, based on the average market excess return. Downside co-skewness for each stock was estimated using daily returns in downside periods. An observation at time $t$ would indicate a downside period if the excess market return at $t$ was below the average market excess return. This can be expressed as:

$$
\operatorname{Coskew}^{-}=\frac{\operatorname{cov}\left(r_{i}, r_{m}^{2} \mid r_{m}<\mu_{m}\right)}{\sqrt{\operatorname{var}\left(r_{i} \mid r_{m}<\mu_{m}\right)} \times \operatorname{var}\left(r_{m} \mid r_{m}<\mu_{m}\right)},
$$

where $r_{i}$ is the excess return on stock $i, r_{m}$ is the market excess return, and $\mu_{m}$ is the average market excess return, $\mu_{m}=\frac{1}{T} \sum r_{m}$. T is the number of observations in the estimated period.

From Equation (1), we can understand why the downside co-skewness proxies for the sustainability to downside risk; a low value of downside co-skewness implies high sustainability. Equation (1) computes the degree of co-movement between a firm's equity return and "squared" market return. Since squared numbers are more magnified when the values have more extreme magnitude, the covariance of a firm's equity return with squared market returns can measure how significantly the equity return co-moves with extreme changes of the market return. Moreover, we conditionally estimate the co-skewness during market downside periods, which implies that the downside co-skewness has a higher value if the equity return co-moves more significantly with extreme drops in the market return. Therefore, firms with low downside co-skewness are more sustainable to market downside risk, which is consistent with our definition of sustainability to downside risk.

\subsubsection{Downside Beta}

Using the concept introduced by Bawa and Lindenberg [37], the downside beta $\left(\beta^{-}\right)$was computed as the covariance of a stock's returns with the market when the market is below its mean. By definition, the downside beta was computed in a similar way to the regular beta, defined as: $\beta=\operatorname{cov}\left(r_{i}, r_{m}\right) / \operatorname{var}\left(r_{m}\right)$, but with observations only in downside periods. We have defined downside beta as:

$$
\beta^{-}=\frac{\operatorname{cov}\left(r_{i}, r_{m} \mid r_{m}<\mu_{m}\right)}{\operatorname{var}\left(r_{m} \mid r_{m}<\mu_{m}\right)}
$$

where $r_{i}$ is the excess return on stock $i, r_{m}$ is the market excess return, and $\mu_{m}$ is the average market excess return, $\mu_{m}=\frac{1}{T} \sum r_{m} ; T$ is the number of observations in the estimated period. This downside beta can also be estimated by running CAPM with downside periods.

The economic implication of downside beta is similar with that of downside co-skewness. The only difference is that downside beta estimates the covariance of equity return with market return (rather than squared market return). Also, since we estimate the conditional covariance during market downside periods, the downside beta measures the degree to which the equity return is sensitive to the market downside return. Thus, sustainable firms' equity values are less sensitive to the market movement during downside periods, resulting in a low value of downside beta. 


\subsection{Portfolio Analysis}

The first goal of this study was to examine the extent to which a downside risk measure was priced in the cross-section of returns. If there was a cross-sectional relationship between the realized average return and the realized factor loading, we would observe the difference in average returns with different factor loadings. In other words, if a downside risk measure is priced, there should be a cross-sectional spread in the average returns of stocks sorted on this measure of risk. Therefore, we have analyzed the pattern between them in portfolios sorted on realized factor loadings. The portfolios were specifically designed as described below.

Over a 12-month period, from $t$ to $t+12$, we calculated the downside co-skewness and realized betas with respect to various risk measures, namely regular beta $\beta$ and downside beta $\beta^{-}$, for each stock, using the daily returns corresponding to Equations (1) and (2), respectively. For the downside beta, we also used another method; during each 12-month period, we ran daily time-series regressions with the CAPM and observations of the downside period to obtain cross-sectional downside betas. At the beginning of the 12-month period at time $t$, estimates of these realized betas and the downside co-skewness calculated for the period from $t$ to $t+12$ were used to sort stocks into five quintile portfolios, ranging from low to high. The stocks within each portfolio varied over each 12-month period. We used overlapping sample periods with a 12-month window and a 1-month step. The sample period extended from January 2000 to December 2016. This means that the first period ran from January 2000 to December 2000 and the next period ran from February 2000 to January 2001. After forming the portfolios, we computed the equal-weighted average of returns for each portfolio over the same 12-month period, using realized factors for sorting. The cross-sectional annual returns were calculated as simple returns, with the beginning and ending stock price for the holding period. We followed Ang et al. [1] and others in examining the contemporaneous relationship between factor loadings and average stock returns. We also computed the average cross-sectional downside co-skewness, as well as the realized $\beta$ and $\beta^{-}$for each portfolio over the same 12-month period with average returns, searching for a common pattern.

Unlike previous studies, which have developed portfolios based on preformation factor loadings, the stocks were directly sorted on the realized factor loadings in the same period as the returns. As in Ang et al. [1], our findings demonstrate that the pattern of cross-sectional returns of stocks sorted on past $\beta^{-}$is unclear. In other words, they show a weak relation between future returns and past $\beta^{-}$.

We used the double-sorted portfolios method to disentangle the effect of downside co-skewness and other risk measures. We controlled for other risk measures by first sorting the stocks into five portfolios, based on two realized betas: regular beta $\beta$ and downside beta $\beta^{-}$, which were estimated for the period ranging from $t$ to $t+12$. We then sorted the stocks into five portfolios, based on downside co-skewness, which was calculated for the period ranging from $t$ to $t+12$, within each first-sorted quintile. After forming 25 portfolios, we calculated the equal-weighted average of realized excess returns for each portfolio over the same 12-month period, from $t$ to $t+12$. In addition, we took the average of the downside co-skewness portfolios across the first-sorted quintiles.

\subsection{Fama-MacBeth Regressions}

The second goal of this study was to examine the explanatory power of downside risk measures and find the premium for downside risk, controlling for other cross-sectional effects simultaneously by using Fama-MacBeth regressions. Our results are based on both individual stocks and 25 portfolios as base assets.

In cases where the individual stocks were base assets, we ran a cross-sectional regression of individual excess returns, which were calculated over the 12-month period ( $t$ to $t+12)$, on realized downside co-skewness, $\beta, \beta^{-}$, estimated for the same 12-month period. We controlled for the effects of firm characteristics, namely the size, book-to-market, and momentum effects, which were all calculated at the beginning of period $t$. The effects of exposure to aggregate liquidity risk [44] also suggested different patterns for the cross-sectional returns. Thus, we also controlled for liquidity beta 
at time $t$. The factor risk premiums were computed as the time series average of estimates from the cross-sectional regressions.

In cases where the portfolios were base assets, stocks were initially sorted into 25 portfolios, based on downside co-skewness calculated over the 12-month period ( $t$ to $t+12)$. We then calculated the equal-weighted average excess returns and independent variables for each portfolio over the same 12-month period ( $t$ to $t+12$ ); the regressions repeated the same procedure used in the case above.

As we used overlapping sample periods with a 12-month window and one-month steps to run the regressions, there was an errors-in-variables problem. To remedy this, the Newey-West standard errors of coefficients [45] with 12 lags were reported. We minimized the effect of potential outliers in the data of all independent variables using the Winsorization method at the $1 \%$ and $99 \%$ levels for each period. This means that we replaced any value of a variable greater than the 99th percentile of all values of that variable with the value of the 99th percentile-and any value below the 1st percentile of all values of that variable with value of the 1st percentile for each period. The Appendix A provides details on the way in which we computed the control variables for the regressions.

\section{Empirical Results}

\subsection{Descriptive Statistics}

Table 1 presents summary statistics for the return and risk measures. Panel A presents descriptive statistics for the cross-sectional returns, calculated as a simple holding period return and downside co-skewness, $\beta^{-}, \beta$, which was calculated as shown in Equations (1) and (2), respectively, for the 12-month period. Panel A reveals that the minimum annual return was $103.89 \%$ and the maximum was $424.02 \%$. The return distribution was positively skewed; hence, the downside risk measures were expected to have explanatory power in the Korean market. The result is compatible with the characteristics of an emerging market as mentioned in Section 1. Downside risk measures are significant for emerging markets because of the asymmetric distribution of emerging stock markets (see, e.g., [36,46]). Panel B shows the correlation matrix containing risk measures. The reported values were a time-series average of the cross-sectional correlations over the sample. The downside beta had the highest correlation with the regular beta (corr: 0.77). The correlation of the downside beta and downside co-skewness was also high (corr: -0.52). In summary, downside risk is relevant in the Korean market and risk measures are highly correlated.

Table 1. Summary statistics.

\begin{tabular}{|c|c|c|c|c|}
\hline \multicolumn{5}{|c|}{ Panel A: Descriptive Statistics } \\
\hline & Return & $\beta$ & $\beta^{-}$ & Coskew \\
\hline Min & -103.89 & 0.00 & -0.14 & -0.71 \\
\hline Max & 424.02 & 1.75 & 2.62 & 0.38 \\
\hline Mean & 10.39 & 0.71 & 0.87 & -0.16 \\
\hline Std.dev & 30.53 & 0.27 & 0.29 & 0.07 \\
\hline Skewness & 2.03 & 0.61 & 0.23 & -0.04 \\
\hline Kurtosis & 38.30 & 0.53 & 2.12 & 11.01 \\
\hline \multicolumn{5}{|c|}{ Panel B: Correlation Matrix } \\
\hline & $\beta$ & $\beta^{-}$ & \multicolumn{2}{|c|}{ Coskew $^{-}$} \\
\hline$\beta$ & 1 & & & \\
\hline$\beta^{-}$ & $0.77^{* * *}$ & 1 & & \\
\hline Coskew & $-0.15^{* * *}$ & $-0.52^{* * *}$ & 1 & \\
\hline
\end{tabular}

Figure 1 displays monthly time-series behavior of equal-weighted aggregate risk measures. Downside risk measures, namely downside beta and downside co-skewness tend to increase during the economic recession. This shows that firms listed in Korean market are more vulnerable to downside 
risk, leading to a firm's equity value that is more sensitive to market risk when the market declines. In other words, firms tend to be less sustainable during downside periods.

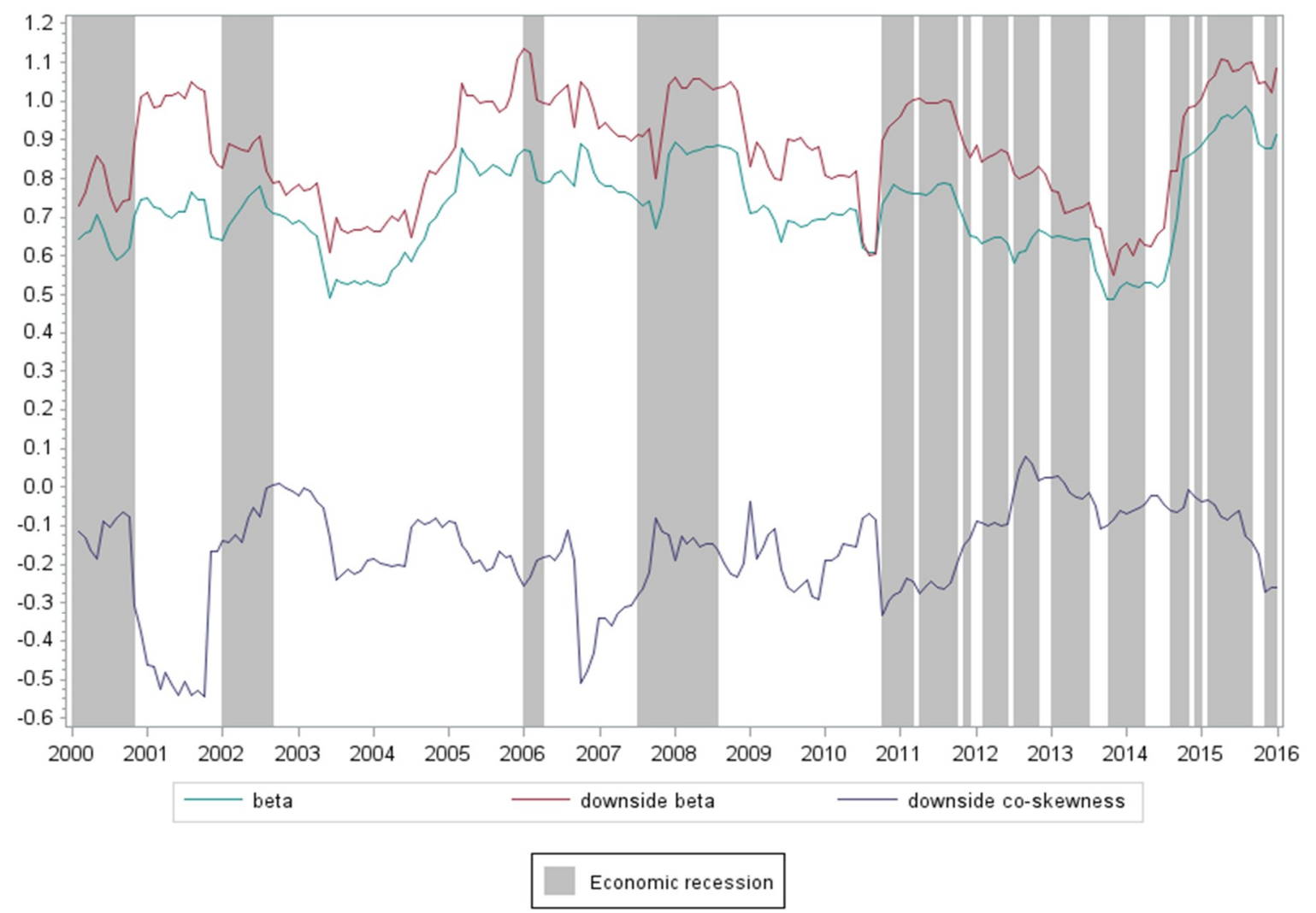

Figure 1. Time series of sustainability measures.

\subsection{Single-Sorted Portfolio}

Table 2 shows the average excess returns and risk characteristics of the equally weighted quintile portfolios sorted by realized betas and realized downside co-skewness. The column labeled "Return" shows the equal-weighted average of returns in excess of the risk-free rate-over the same period used to compute the realized risk factors for each portfolio. The columns labeled $\beta, \beta^{-}$and Coskew $w^{-}$ represent the time-series and cross-sectional average of these realized risk measures, which were also estimated over the same 12-month period. The row labeled "High-low" refers to value differences between the highest and lowest sorted portfolios. Newey-West $t$-statistics [45] are included in parentheses below each coefficient.

As mentioned in Section 2, the traditional risk measure, CAPM beta, cannot adequately explain the cross-section of returns in the Korean market. Although downside risk is more relevant, the common measure of downside risk, namely downside beta (introduced by Ang et al. [1]) is not appropriate for the Korean market. This finding is confirmed by the results of this study, as shown in Panels A and B of Table 2.

Panel A reports the results of portfolios sorted using regular beta. The relation between average returns and realized $\beta$ is not clear. The spread in equal-weighted averages of excess returns between Portfolios 5 and 1 was $0.64 \%$ per annum, statistically insignificant. The realized $\beta$ ranged from 0.24 to 1.27 , a spread of 1.03. Many previous papers have reported that the relation between average return and beta is flat. For example, Fama and French [47] argued that this reflects the effect of size; Jegadeesh and Titman [48] showed that the failure of regular beta relates to the effect of momentum. Our results show the limitations of CAPM beta in measuring systematic risk in the Korean market, with positively skewed market return distributions. Panel B shows what happens if we sort on downside beta instead 
of regular beta. There is no clear relationship between average returns and realized $\beta^{-}$. The difference between the average returns of Portfolios 5 and 1 was $-0.39 \%$ per annum, statistically insignificant.

As a result of Panels A and B, regular and downside beta were not appropriate measures of downside risk in the Korean market. Therefore, we examined the extent to which another measure of downside risk, downside co-skewness, could explain cross-sectional stock returns in the Korean market. The results are described in Panel C of Table 2.

Panel $\mathrm{C}$ shows stocks sorted on downside co-skewness. The average returns increased from $11.47 \%$ to $18.46 \%$, a spread of $6.99 \%$ per annum, statistically significant at the $5 \%$ level. The downside co-skewness ranged from -0.34 to 0.02 , a spread of 0.36 . Stocks with higher downside co-skewness had higher average returns. This result was consistent with previous studies. Galagedera and Brooks $[11,12]$ also found in emerging markets that the spread in cross-sectional average returns between high-risk and low-risk portfolios is slightly higher in portfolios sorted on downside co-skewness than in portfolios sorted on downside beta or CAPM beta. Moreover, the higher downside co-skewness is the higher average returns. Stocks that were more sensitive to market risk when the market declined were found to accrue larger losses in declining markets; as a result, they could not attract investors to hold them. For this reason, investors require higher compensation to hold such stocks.

The results above show that sorting stocks based on downside co-skewness leads to a more significant cross-sectional spread in average returns than sorting on other measures of downside risk. Therefore, it is clear that downside co-skewness is better than other risk measures in explaining cross-sectional stock returns in the Korean market. Moreover, the higher the downside co-skewness, the higher the average return.

The single-sorted portfolio analysis also provides important economic implications on the relationship between the sustainability and the cost of equity. Sorted by downside co-skewness, the most sustainable firms (low-portfolio) can reduce their cost of equity capital by $7 \%$ compared to the least sustainable firms (high-portfolio). The sustainability spread between the two groups is 0.36 as measured by downside co-skewness. If we assume that the relation is linear, unit increase in sustainability to downside risk can lead to a $20 \%(=7 \% / 0.36)$ reduction in cost of equity. This rough calculation is consistent with the result of model III that will be shown in Table 4 in Section 4.4. The Fama-MacBeth regression result shows the coefficient for downside co-skewness is approximately 20.

Table 2. Single-sorted portfolios.

\begin{tabular}{ccccccccc}
\hline \multicolumn{3}{c}{ Panel A: Sorted on $\beta$} & \multicolumn{3}{c}{ Panel B: Sorted on $\beta^{-}$} & \multicolumn{3}{c}{ Panel C: Sorted on coskew } \\
\hline Portfolio & Return & $\beta$ & Portfolio & Return & $\beta^{-}$ & Portfolio & Return & coskew $^{-}$ \\
\hline 1 Low & 18.30 & 0.24 & 1 Low & 19.46 & 0.22 & 1 Low & 11.47 & -0.34 \\
& $(3.21)$ & $(11.21)$ & & $(3.15)$ & $(5.63)$ & & $(1.98)$ & $(-11.15)$ \\
2 & 15.59 & 0.50 & 2 & 14.80 & 0.62 & 2 & 15.86 & -0.24 \\
& $(2.77)$ & $(20.28)$ & & $(2.81)$ & $(18.59)$ & & $(2.83)$ & $(-8.64)$ \\
3 & 15.51 & 0.69 & 3 & 16.18 & 0.87 & 3 & 19.45 & -0.17 \\
& $(2.60)$ & $(26.67)$ & & $(2.79)$ & $(28.94)$ & & $(3.29)$ & $(-6.72)$ \\
4 & 15.94 & 0.90 & 4 & 14.72 & 1.12 & 4 & 18.88 & -0.10 \\
5 & $(2.47)$ & $(33.84)$ & & $(2.36)$ & $(38.41)$ & & $(2.85)$ & $(-4.38)$ \\
5 High & 18.93 & 1.27 & 5 High & 19.07 & 1.55 & 5 High & 18.46 & 0.02 \\
\multirow{2}{*}{ High-low } & $(2.37)$ & $(45.41)$ & & $(2.50)$ & $(44.88)$ & & $(2.64)$ & $(0.98)$ \\
& 0.64 & $1.03 * * *$ & High-low & -0.39 & $1.33 * * *$ & High-low & $6.99 * *$ & $0.36 * * *$ \\
& $(0.12)$ & $(52.44)$ & & $(-0.11)$ & $(27.73)$ & & $(2.06)$ & $(27.57)$ \\
\hline
\end{tabular}

Note: ${ }^{* * *}$ and ${ }^{* *}$ indicate significance at the $1 \%$ and $5 \%$ levels, respectively.

\subsection{Double-Sorted Portfolio}

The above results for single-sorted portfolios clearly reveal that downside co-skewness is a more relevant measure of downside risk in the Korean market than other measures. However, these measures 
all capture the effect of downside risk in asset pricing. They are also highly correlated, as described in Section 4.1.

Table 3 shows the results for double-sorted portfolios, disentangling the effect of downside co-skewness and other risk measures. Over every 12-month period, we calculated Coskew $w^{-}$and realized $\beta^{-}$for all stocks listed on the KOSPI market, using daily simple holding returns. In Panel $\mathrm{A}$, at the beginning of the 12-month period, we first sorted stocks into five quintiles, based on $\beta$ which were estimated over the next 12 months. We then sorted stocks in each $\beta$ quintile into five quintile portfolios, based on the Coskew ${ }^{-}$estimated over the next 12 months. Panel B repeats the same procedure as Panel A, except that we first sorted stocks on realized $\beta^{-}$and then on Coskew ${ }^{-}$. The coefficients are the equal-weighted average realized return, in excess of the risk-free rate, over the same 12-month period as the Coskew $w^{-}, \beta$, and $\beta^{-}$. The row labeled "High-low" refers to the differences in values between the highest and lowest sorted portfolios. The "Average" column reports the average excess return of stocks within each second-sort quintile. Newey-West $t$-statistics are reported in parentheses below each coefficient.

Table 3. Double-sorted portfolios.

\begin{tabular}{|c|c|c|c|c|c|c|}
\hline Portfolio & 1 & 2 & 3 & 4 & 5 & Average \\
\hline \multicolumn{7}{|c|}{ Panel A: Controlled for $\beta$} \\
\hline \multirow[t]{2}{*}{1 Low } & 13.36 & 9.58 & 9.08 & 8.97 & 15.28 & 11.25 \\
\hline & $(2.31)$ & $(1.73)$ & $(1.69)$ & $(1.49)$ & $(1.98)$ & (1.97) \\
\hline \multirow[t]{2}{*}{2} & 17.47 & 14.21 & 11.97 & 11.99 & 21.35 & 15.40 \\
\hline & (3.33) & $(2.81)$ & $(2.16)$ & $(2.11)$ & $(2.68)$ & $(2.81)$ \\
\hline \multirow[t]{2}{*}{3} & 20.38 & 18.92 & 19.39 & 15.47 & 19.08 & 18.65 \\
\hline & (3.37) & $(3.26)$ & $(3.28)$ & $(2.53)$ & $(2.35)$ & $(3.15)$ \\
\hline \multirow[t]{2}{*}{4} & 19.34 & 17.18 & 18.27 & 18.72 & 18.25 & 18.35 \\
\hline & (3.19) & $(2.86)$ & $(2.68)$ & $(2.67)$ & $(2.19)$ & $(2.82)$ \\
\hline \multirow[t]{2}{*}{5 High } & 20.81 & 17.87 & 18.60 & 24.43 & 20.71 & 20.48 \\
\hline & (3.13) & $(2.68)$ & $(2.52)$ & $(2.79)$ & $(2.37)$ & $(2.82)$ \\
\hline High-low & 7.45 * & $8.29 * *$ & $9.52 *$ & $15.46^{* * *}$ & 5.43 & $9.23^{* *}$ \\
\hline \multirow[t]{2}{*}{$t$-stat } & $(1.80)$ & $(2.21)$ & $(1.96)$ & $(2.76)$ & $(1.36)$ & $(2.50)$ \\
\hline & \multicolumn{5}{|c|}{ Panel B: Controlled for $\beta^{-}$} & \\
\hline \multirow[t]{2}{*}{1 Low } & 15.05 & 8.87 & 9.48 & 8.41 & 11.59 & 10.68 \\
\hline & $(2.91)$ & (1.91) & $(1.82)$ & (1.43) & (1.78) & (2.03) \\
\hline \multirow[t]{2}{*}{2} & 20.13 & 12.00 & 15.40 & 11.09 & 18.07 & 15.34 \\
\hline & (3.35) & (2.59) & $(2.71)$ & $(1.93)$ & $(2.50)$ & $(2.71)$ \\
\hline \multirow[t]{2}{*}{3} & 19.87 & 19.38 & 17.02 & 12.58 & 19.33 & 17.64 \\
\hline & (3.08) & $(3.26)$ & $(2.93)$ & $(2.24)$ & $(2.65)$ & $(2.98)$ \\
\hline \multirow[t]{2}{*}{4} & 24.07 & 16.78 & 19.17 & 19.47 & 23.24 & 20.55 \\
\hline & $(2.66)$ & $(2.96)$ & $(2.84)$ & $(2.90)$ & $(2.94)$ & $(2.98)$ \\
\hline \multirow[t]{2}{*}{5 High } & 18.06 & 16.76 & 19.73 & 21.83 & 22.79 & 19.83 \\
\hline & (3.03) & $(2.57)$ & $(2.83)$ & $(2.54)$ & $(2.15)$ & $(2.68)$ \\
\hline High-low & 3.01 & $7.88^{*}$ & $10.25^{* *}$ & $13.42^{* *}$ & 11.20 * & $9.15^{* *}$ \\
\hline$t$-stat & $(0.86)$ & $(1.80)$ & $(2.23)$ & $(2.38)$ & $(1.68)$ & $(2.07)$ \\
\hline
\end{tabular}

Note: ${ }^{* * *}, * *$, and ${ }^{*}$ indicate significance at the $1 \%, 5 \%$, and $10 \%$ levels, respectively.

Panel A shows the results associated with sorting stocks, based on downside co-skewness, after controlling for regular beta. The stocks were first sorted using regular beta. Then, within each regular beta-sorted portfolio, stocks were sorted using downside co-skewness. The "Average" column reports the average 12-month excess returns of the downside co-skewness portfolios, controlling for regular beta. The row labeled "high-low" shows the difference in average stock returns between the highest and lowest downside co-skewness portfolios within each regular beta portfolio. The average returns of the downside co-skewness portfolios are significant, and the difference, in average returns, between the fifth and first downside co-skewness portfolio is $9.23 \%$ per annum, which is also significant 
( $t$-statistic is 2.5) after controlling for regular beta. This result suggests that downside co-skewness captures priced risk, which is not captured by regular beta.

Panel B shows the results after controlling for downside beta. Panel B repeats the same procedure as Panel A, except that the stocks are first sorted using realized $\beta^{-}$and then downside co-skewness. Controlling for downside beta, the difference in average returns between the fifth and first downside co-skewness portfolios was $9.15 \%$ per annum, which is significant ( $t$-statistic is 2.07$)$. This result reveals that downside co-skewness captures priced downside risk more effectively than downside beta.

To sum, the double-sorted portfolio analysis reveals that downside co-skewness is a better proxy of sustainability to downside risk, compared to downside beta. When we compare sustainable firms (low-portfolio) and vulnerable firms (high-portfolio), we can see that their costs of equity capital are significantly different even after controlling for other potential proxy of sustainability. The spread is approximately $9 \%$ on average, which means that, everything else being equal, sustainable firms can raise their equity capital at $9 \%$ lower cost than vulnerable firms should pay.

\subsection{Fama-MacBeth Regression}

The results derived from the single-sorted and double-sorted portfolios described in Sections 4.2 and 4.3 reveal that downside co-skewness is a more appropriate measure in the Korean market than downside beta or regular beta. They also capture the priced downside risk beyond regular and downside beta. In this section, the results of the cross-sectional regressions are reported in Table 4 to further explore the explanatory power of downside co-skewness, after controlling for other cross-sectional effects simultaneously. In Panel A, we ran a regression of 12-month excess returns of individual stocks on firm and risk characteristics. In Panel B, 12-month excess returns of 25 portfolios, sorted using Coskew ${ }^{-}$, are used as a dependent variable. The log market capitalization of the firm ('Size"), book-to-market ratio ("B/M") and past 12-months of excess returns ("Past Ret") are the firm characteristics calculated at the beginning of each 12-month period. Realized Coskew ${ }^{-}, \beta$, and $\beta^{-}$ are the realized risk characteristics calculated over the same 12-month period as the realized excess returns. We also included the liquidity betas $\left(\beta_{\mathrm{L}}\right)[44]$ to proxy for exposure to aggregate liquidity risk. Newey-West $t$-statistics are reported in parentheses below each coefficient. The row labeled "Adj. $R^{2 \text { " }}$ reports the time-series average of adjusted $R^{2}$. All independent variables are Winsorized at the $1 \%$ and $99 \%$ levels.

Panel A shows the results of regressions when individual stocks are the base assets. Regressions I, II, and III show the results of univariate regressions with only one risk measure as an independent variable. The first regression reports the results of one-factor CAPM and finds no significant relationship between stock returns and regular beta. This confirms the findings of previous studies [47-51]. In Regressions II and III, the regular beta was replaced by downside risk measures. When the downside beta was used as a downside risk measure, the premium for the downside beta was statistically insignificant. This is consistent with results of sorted portfolios in Section 4.2. Alles and Murray [15] also concluded that premium for downside risk measured by downside beta was insignificant in emerging Asian markets. Interestingly, the downside risk was priced in the cross-sectional returns when the downside risk was measured by downside co-skewness. The premium for downside co-skewness was $19.25 \%$ and statistically significant ( $t$-value was 1.76 ). When regular and downside beta were included, along with downside co-skewness in Regressions IV and V, only the premium for downside co-skewness was shown to be significant. This further confirms the explanatory power of downside co-skewness in cross-sectional variations of the Korean stock market. Regression VI found the premium for downside risk represented by downside co-skewness, when controlling for firm characteristics, including the size, book-to-market, and momentum effects. Including these characteristics only strengthened the premium for downside risk. This premium remained positive, at $22.706 \%$, and significant, with a $t$-value of 2.18 . Regression VII examined the premium for downside risk, controlling for all firm characteristics and the aggregate liquidity risk. Regression VII showed 
that, when we account for aggregate liquidity risk, the premium for bearing downside risk remains positive at $23.097 \%$ and significant, with a $t$-value of 2.22 .

Table 4. Cross-sectional regressions.

\begin{tabular}{|c|c|c|c|c|c|c|c|}
\hline Model & $\mathbf{I}$ & II & III & IV & V & VI & VII \\
\hline \multicolumn{8}{|c|}{ Panel A: Regression using individual stocks } \\
\hline Intercept & $\begin{array}{c}15.922 * * * \\
(2.77)\end{array}$ & $\begin{array}{c}18.488^{* * * *} \\
(3.29)\end{array}$ & $\begin{array}{c}22.057^{* * * *} \\
(3.16)\end{array}$ & $\begin{array}{c}21.577^{* * * *} \\
(3.64)\end{array}$ & $\begin{array}{c}22.592^{* * *} \\
(3.88)\end{array}$ & $\begin{array}{c}58.569^{* * * *} \\
(3.00)\end{array}$ & $\begin{array}{c}59.624^{* * *} \\
(3.05)\end{array}$ \\
\hline$\beta$ & $\begin{array}{l}0.322 \\
(0.05)\end{array}$ & & & $\begin{array}{l}4.654 \\
(0.68)\end{array}$ & & & \\
\hline$\beta^{-}$ & & $\begin{array}{l}-1.777 \\
(-0.55)\end{array}$ & & & $\begin{array}{l}5.664 \\
(1.03)\end{array}$ & & \\
\hline Coskew ${ }^{-}$ & & & $\begin{array}{c}19.246 \text { * } \\
(1.76)\end{array}$ & $\begin{array}{c}37.229 * * \\
(2.47)\end{array}$ & $\begin{array}{c}41.976 \text { * } \\
(1.96)\end{array}$ & $\begin{array}{c}22.706^{* *} \\
(2.18)\end{array}$ & $\begin{array}{c}23.097 \text { ** } \\
(2.22)\end{array}$ \\
\hline Size & & & & & & $\begin{array}{c}-3.040 * * \\
(-2.25)\end{array}$ & $\begin{array}{c}-3.133^{* *} \\
(-2.33)\end{array}$ \\
\hline$B / M$ & & & & & & $\begin{array}{c}0.242^{* * *} \\
(2.99)\end{array}$ & $\begin{array}{c}0.244^{* * *} \\
(3.11)\end{array}$ \\
\hline Past Ret & & & & & & $\begin{array}{c}0.037^{* *} \\
(2.13)\end{array}$ & $\begin{array}{c}0.034^{* *} \\
(2.00)\end{array}$ \\
\hline$\beta_{L}$ & & & & & & & $\begin{array}{l}3.733 \\
(1.22)\end{array}$ \\
\hline Adj. $R^{2}$ & $\begin{array}{c}0.024^{* * *} \\
(5.88)\end{array}$ & $\begin{array}{c}0.014^{* * *} \\
(4.09)\end{array}$ & $\begin{array}{c}0.006^{* * *} \\
(3.90)\end{array}$ & $\begin{array}{c}0.032 * * * \\
(6.57)\end{array}$ & $\begin{array}{c}0.025 * * * \\
(5.52)\end{array}$ & $\begin{array}{c}0.035^{* * *} \\
(6.84)\end{array}$ & $\begin{array}{c}0.037^{* * *} \\
(7.57)\end{array}$ \\
\hline \multicolumn{8}{|c|}{ Panel B: Regression using 25 portfolios } \\
\hline Intercept & $\begin{array}{c}28.310^{* * *} \\
(3.45)\end{array}$ & $\begin{array}{c}22.560 * * * \\
(2.76)\end{array}$ & $\begin{array}{c}21.913^{* * * *} \\
(3.15)\end{array}$ & $\begin{array}{c}17.996^{* * *} \\
(2.73)\end{array}$ & $\begin{array}{c}19.446^{* * *} \\
(2.78)\end{array}$ & $\begin{array}{c}51.380 * * \\
(2.25)\end{array}$ & $\begin{array}{c}52.307^{* *} \\
(2.33)\end{array}$ \\
\hline$\beta$ & $\begin{array}{c}-16.237^{* *} \\
(-2.42)\end{array}$ & & & $\begin{array}{l}6.471 \\
(0.88)\end{array}$ & & & \\
\hline$\beta^{-}$ & & $\begin{array}{l}-5.777 \\
(-1.29)\end{array}$ & & & $\begin{array}{l}3.740 \\
(0.69)\end{array}$ & & \\
\hline Coskew ${ }^{-}$ & & & $\begin{array}{c}19.080 \text { * } \\
(1.74)\end{array}$ & $\begin{array}{c}30.493 * * \\
(1.98)\end{array}$ & $\begin{array}{c}29.441 \text { * } \\
(1.66)\end{array}$ & $\begin{array}{c}20.649 * \\
(1.90)\end{array}$ & $\begin{array}{c}19.894 \text { * } \\
(1.88)\end{array}$ \\
\hline Size & & & & & & $\begin{array}{l}-2.515 \\
(-1.47)\end{array}$ & $\begin{array}{l}-2.597 \\
(-1.55)\end{array}$ \\
\hline$B / M$ & & & & & & $\begin{array}{l}0.249 \\
(1.14)\end{array}$ & $\begin{array}{l}0.200 \\
(0.88)\end{array}$ \\
\hline Past Ret & & & & & & $\begin{array}{c}0.071^{* *} \\
(2.32)\end{array}$ & $\begin{array}{l}0.060 * \\
(1.84)\end{array}$ \\
\hline$\beta_{L}$ & & & & & & & $\begin{array}{l}5.976 \\
(0.97)\end{array}$ \\
\hline $\operatorname{Adj} \cdot R^{2}$ & $\begin{array}{c}0.090 * * * \\
(3.97)\end{array}$ & $\begin{array}{c}0.085^{* * *} \\
(3.95)\end{array}$ & $\begin{array}{c}0.111^{* * *} \\
(4.15)\end{array}$ & $\begin{array}{c}0.143^{* * *} \\
(5.10)\end{array}$ & $\begin{array}{c}0.133^{* * *} \\
(4.66)\end{array}$ & $\begin{array}{c}0.138^{* * *} \\
(5.23)\end{array}$ & $\begin{array}{c}0.136 \text { *** } \\
(4.86)\end{array}$ \\
\hline
\end{tabular}

Note: ${ }^{* * *}, * *$, and ${ }^{*}$ indicate significance at the $1 \%, 5 \%$, and $10 \%$ levels, respectively.

Panel B shows the results of regressions with portfolios as base assets. Regression I reported a negative premium for regular beta. However, the one-factor CAPM was rejected because regular $\beta$ did not adequately explain the cross-section of stock returns $[47,48]$. The premium for downside beta in Regression II was statistically insignificant; the premium for downside co-skewness in Regression III was $19.08 \%$ and statistically significant ( $t$-value was 1.74 ). Both the premiums for downside co-skewness and regular beta were significant; the adjusted $\mathrm{R}^{2}$ in Regression III, with downside co-skewness as an independent variable (adj. $R^{2}=0.111$ ), was higher than Regression I with regular beta as the independent variable. Thus, downside co-skewness is still the most appropriate measure in asset pricing. Moreover, the premium for regular beta became insignificant when downside co-skewness was included in Regression IV. In Regression V, when both downside beta and downside 
co-skewness were included, only the premium for downside co-skewness remained statistically significant. When controlling for all cross-sectional effects in Regression VII, the premium for downside co-skewness remained positive at $19.89 \%$ and significant, with a $t$-value of 1.88 .

The results in these two cases are similar; they show that downside co-skewness has explanatory power in asset pricing, after controlling for other cross-sectional effects taking place simultaneously. Moreover, the reward for downside risk, measured by downside co-skewness, is significantly positive, at approximately $19 \%$ per annum. This means that stocks with high downside co-skewness are compensated for by high average returns. This positive relation between downside co-skewness and average return has also been found in previous studies in emerging markets [11,15].

The regression results also provide implications on the relation between the sustainability and the cost of equity. As the sustainability is measured by downside co-skewness, a unit increase in sustainability can reduce the cost of equity by $19 \%$, controlling for firm size, book-to-market equity ratio, and other determinants of the cost of equity. This finding is helpful to financial managers who decide to raise capital by equity.

\section{Conclusions}

This study has built on previous studies carried out in emerging markets to propose downside co-skewness as an appropriate measure of downside risk, and to examine its explanatory power in cross-sectional stock returns in the Korean market.

This research has produced several important findings. First, the results confirm that downside risk is priced in asset pricing in the Korean stock market. Downside co-skewness outperforms both the CAPM and downside beta in explaining the cross-section of stock returns. Second, the effect of downside co-skewness is different from the effects of downside beta and regular beta. The results show that, when controlling for downside beta or regular beta, the difference in average returns between the lowest and highest downside co-skewness portfolios remains significantly positive. Third, the results also show that the premium for downside co-skewness is significantly positive, at approximately $19 \%$ per annum. These findings show that investors require compensation for bearing downside risk, as measured by downside co-skewness in the Korean stock market.

We also provide implications on the relationship between firms' sustainability and their cost of equity capital. Moreover, our results implies that firms that are more sustainable to downside business risk can finance their equity at $19 \%$ lower costs. From this study, managers should make strategic investments to improve the sustainability of the company so that a company can enjoy a lower cost of equity.

This study needs to be extended to address the following limitations in future research: first, this study employs realized returns to proxy for the cost of equity capital or expected returns. This study is based on the assumption that unexpected returns due to a new information portion of realized return is mean zero. Botosan et al. [52] argued that realized returns are not a reliable proxy of expected returns. Previous papers have suggested different sets of proxies for expected returns. For example, Guay et al. [53] suggested five proxies and Easton et al. [54] also suggested seven proxies for expected returns. Botosan and Plumlee [55] concluded that among five proxies suggested, only $r_{D I V}$ $\left(r_{D I V}\right.$ is calculated based on the target price method [52]) and $r_{P E G}\left(r_{P E G}\right.$ is calculated based on the price-earnings-growth ratio method [52]) are valid proxies for expected returns. Botosan et al. [52] also recommended that researchers should employ either $r_{D I V}$ or $r_{P E G}$ to proxy for expected returns. Moreover, these studies have supported the notion of researchers evaluating the validity of any new proxies for expected return by demonstrating a consistent and predictable association between the proxy and future return.

Second, this study has not focused on firms whose strategy is to finance with debt. The debt market clearly considers risk differently from the stock market. Investing in strategies that improve the company's sustainability is likely to lead to higher costs of debt. For example, Sharfman and Fernando [27] found a positive relation between environmental risk management and cost of debt. 
The cost of debt result is contrasted to the cost of equity result. Thus, future research can extend our study by examining the cost of debt or the combination of both costs as the weighted average cost of capital.

Author Contributions: The authors contributed to this paper as follows. T.T.T.T.: software, formal analysis, investigation, data curation, writing — original draft preparation; J.K.: methodology, validation, writing —review and editing, supervision, project administration.

Funding: This research received no external funding.

Conflicts of Interest: The authors declare no conflict of interest.

\section{Appendix A}

Control variables in the regression model are described in detail as follows:

- Size

The size effect is represented using each firm's natural logarithm of market capitalization. Market capitalization equals the price multiplied by shares outstanding each month.

- Book-to-market

The book-to-market ratio assigned to a firm from April of year $t$ to March of year $t+1$ is the book equity at the end of fiscal year $t-1$ divided by the market capitalization in December of year $t-1$. Book equity is the value of the stockholders' equity, plus all deferred taxes and investment tax credit, minus the value of preferred stock; it is announced annually.

\section{- Momentum}

The momentum effect involves the firm's excess returns for the past 12 months. Specifically, for period from $t$ to $t+12$, past excess returns are calculated as the change in price for the holding 12-month period, with the beginning stock price and the closing stock price ranging from $t-12$ to $t-1$.

- Beta of liquidity

We controlled exposure to aggregate liquidity risk, represented by the liquidity beta [44], at time $t$. To estimate the liquidity beta for each stock listed on the KOSPI market at the end of each month, we ran time-series regressions via the following model, using monthly data from the previous five years:

$$
r_{i, t}=\beta_{i}^{0}+\beta_{i}^{L} L_{t}+\beta_{i}^{M} M K T_{t}+\beta_{i}^{S} S M B_{t}+\beta_{i}^{H} H M L_{t}+\varepsilon_{i, t}
$$

where $r_{i, t}$ denoted the excess return of stock $i$ and $L_{t}$ was the innovation in aggregate liquidity. MKT was the market factor, $S M B$ was the size factor and $H M L$ was the book-to-market factor, relative to the Fama-French three factor [56].

$L_{t}$ was constructed, following Pástor and Stambaugh [44]. Daily stock return and daily dollar volume data are available on DataGuide. They first constructed estimates of liquidity measure $\left(\gamma_{i, t}\right)$, which used signed order flow for an individual stock $i$ in month $t$, by running the following regression using daily data:

$$
r_{i, d+1, t}^{e}=\theta_{i, t}+\varnothing_{i, t} r_{i, d, t}+\gamma_{i, t} \operatorname{sign}\left(r_{i, d, t}^{e}\right) \times v_{i, d, t}+\varepsilon_{i, d+1, t},
$$

where $r_{i, d, t}$ is the return on stock $i$ on day $d$ in month $t . r_{i, d, t}^{e}=r_{i, d, t}-r_{m, d, t}$ is stock return in excess of the market return and $r_{m, d, t}$ is the market return on day $d$ in month $t . v_{i, d, t}$ is the dollar volume for stock $i$ on day $d$ in month $t$.

They then scaled the monthly cross-sectional average of difference in liquidity measures to construct innovations in aggregate liquidity:

$$
\Delta \hat{\gamma}_{t}=\left(\frac{m_{t}}{m_{1}}\right) \times \frac{1}{N} \sum_{i=1}^{N}\left(\hat{\gamma}_{i, t}-\hat{\gamma}_{i, t-1}\right),
$$


where $m_{t}$ is the total dollar value of the included stocks at the end of month $t-1$, and $m_{1}$ is the total dollar value of stocks at the end of January 2000. $N$ is the number of available stocks at month $t$. The innovations in liquidity are computed as the residuals in the following regression:

$$
\Delta \hat{\gamma}_{t}=a+b \Delta \hat{\gamma}_{t-1}+c\left(\frac{m_{t-1}}{m_{1}}\right) \hat{\gamma}_{t-1}+\mu_{t}
$$

where $\hat{\gamma}_{t-1}$ is the lagged value of the cross-sectional average of liquidity measures in month $t$, estimated using $\hat{\gamma}_{t}=(1 / N) \sum_{i=1}^{N} \hat{\gamma}_{i, t}$, with $N$ as the number of stocks at month $t$. Finally, the aggregate liquidity measure, $L_{t}$, is taken to be the fitted residual multiplied by $10^{9}, L_{t}=\hat{\mu}_{t} \times 10^{9}$. The scaling simply produces more convenient magnitudes of the liquidity betas.

\section{References}

1. Ang, A.; Chen, J.; Xing, Y. Downside Risk. Source Rev. Financ. Stud. 2006, 19, 1191-1239. [CrossRef]

2. Farago, A.; Tédongap, R. Downside Risks and the Cross-Section of Asset Returns. SSRN Electron. J. 2017. [CrossRef]

3. Menezes, C.; Geiss, C.; Tressler, J. Increasing Downside Risk. Am. Econ. Rev. 1980, 70, 921-932.

4. Gul, F. A Theory of Disappointment Aversion. Econometrica 1991, 59, 667. [CrossRef]

5. Kim, M.K.; Zumwalt, J.K. An Analysis of Risk in Bull and Bear Markets. Source J. Financ. Quant. Anal. 1979, 14, 1015-1025. [CrossRef]

6. Kahneman, D.; Tversky, A. Prospect theory: An analysis of decisions under risk. Econometrica 1979, 47, 263-291. [CrossRef]

7. Tversky, A.; Kahneman, D. Loss aversion in riskless choice: A reference-dependent model. Q. J. Econ. 1991, 106, 1039-1061. [CrossRef]

8. Chen, D.-H.; Chen, C.-D.; Chen, J. Downside risk measures and equity returns in the NYSE. Appl. Econ. 2009, 41, 1055-1070. [CrossRef]

9. Post, T.; Van Vliet, P. Downside risk and asset pricing. J. Bank. Financ. 2006, 30, 823-849. [CrossRef]

10. Estrada, J. Systematic risk in emerging markets: The D-CAPM. Emerg. Mark. Rev. 2002, 3, 365-379. [CrossRef]

11. Galagedera, D.U.A.; Brooks, R.D. Is co-skewness a better measure of risk in the downside than downside beta?. Evidence in emerging market data. J. Multinatl. Financ. Manag. 2007, 17, 214-230. [CrossRef]

12. Galagedera, D.U.A. Economic significance of downside risk in developed and emerging markets. Appl. Econ. Lett. 2009, 16, 1627-1632. [CrossRef]

13. Bekaert, G.; Erb, C.B.; Harvey, C.R.; Viskanta, T.E. Distributional Characteristics of Emerging Market Returns and Asset Allocation. J. Portf. Manag. 1998, 24, 102-116. [CrossRef]

14. Rashid, A.; Hamid, F. Downside risk analysis of returns on the Karachi Stock Exchange. Manag. Financ. 2015, 41, 940-957. [CrossRef]

15. Alles, L.; Murray, L. Rewards for downside risk in Asian markets. J. Bank. Financ. 2013, 37, $2501-2509$. [CrossRef]

16. Fama, E.F.; MacBeth, J.D. Risk, Return, and Equilibrium: Empirical Tests. J. Polit. Econ. 1973, 81, 607-636. [CrossRef]

17. Hoon Moon, T. Sustainable Development in Korea, Key Issues and Government Response. Int. Rev. Public Adm. 2006, 11, 1-18. [CrossRef]

18. Moon, T.H. Korea's Sustainable Development Strategy. Korea Obs. 2009, 40, 85-114.

19. Son, H.; Kim, C.; Chong, W.K.; Chou, J.-S. Implementing sustainable development in the construction industry: Constructors' perspectives in the US and Korea. Sustain. Dev. 2011, 19, 337-347. [CrossRef]

20. Baek, H.; Park, S.K. Sustainable development plan for Korea through expansion of green IT: Policy issues for the effective utilization of big data. Sustainability 2015, 7, 1308-1328. [CrossRef]

21. Dyllick, T.; Hockerts, K. Beyond the business case for corporate sustainability. Bus. Strategy Environ. 2002, 11, 130-141. [CrossRef]

22. Schaltegger, S.; Burritt, R.; Petersen, H. An introduction to corporate environmental management: Striving for sustainability. Manag. Environ. Qual. Int. J. 2003, 14, 541-542. [CrossRef] 
23. Anderson, D.R. The critical importance of sustainability risk management. Risk Manag. 2006, 53, 66.

24. Godfrey, P.C.; Merrill, C.B.; Hansen, J.M. The relationship between corporate social responsibility and shareholder value: An empirical test of the risk management hypothesis. Strateg. Manag. J. 2009, 30, 425-445. [CrossRef]

25. Ng, A.C.; Rezaee, Z. Business sustainability performance and cost of equity capital. J. Corp. Financ. 2015, 34, 128-149. [CrossRef]

26. Lourenço, I.C.; Branco, M.C. Determinants of corporate sustainability performance in emerging markets: The Brazilian case. J. Clean. Prod. 2013, 57, 134-141. [CrossRef]

27. Sharfman, M.P.; Fernando, C.S. Environmental risk management and the cost of capital. Strateg. Manag. J. 2008, 29, 569-592. [CrossRef]

28. El Ghoul, S.; Guedhami, O.; Kwok, C.C.Y.; Mishra, D.R. Does corporate social responsibility affect the cost of capital? J. Bank. Financ. 2011, 35, 2388-2406. [CrossRef]

29. Dhaliwal, D.S.; Li, O.Z.; Tsang, A.; Yang, Y.G. Voluntary Nonfinancial Disclosure and the Cost of Equity Capital: The Initiation of Corporate Social Responsibility Reporting. Account. Rev. 2011, 86, 59-100. [CrossRef]

30. Matthiesen, M.-L.; Salzmann, A.J. Corporate social responsibility and firms' cost of equity: How does culture matter? Cross Cult. Strateg. Manag. 2017, 24, 105-124. [CrossRef]

31. Reverte, C. The Impact of Better Corporate Social Responsibility Disclosure on the Cost of Equity Capital. Corp. Soc. Responsib. Environ. Manag. 2012, 19, 253-272. [CrossRef]

32. Feng, Z.Y.; Wang, M.L.; Huang, H.W. Equity financing and social responsibility: Further international evidence. Int. J. Account. 2015, 50, 247-280. [CrossRef]

33. Xu, S.; Liu, D.; Huang, J. Corporate social responsibility, the cost of equity capital and ownership structure: An analysis of Chinese listed firms. Aust. J. Manag. 2015, 40, 245-276. [CrossRef]

34. Waliuddin, M.; Razali, M.; Fui, W.Y.; Shaharuddin, S.; Hisham Tak, A.; Uzairi, M.; Hajazi, A. Corporate social responsibility disclosure and cost of equity capital in industrial product industry. J. Humanit. Lang. Cult. Bus. 2017, 1, 168-180.

35. Post, T.; Van Vliet, P. Conditional Downside Risk and the CAPM; Erasmus Research Institute of Management: Rotterdam, The Netherlands, 2004; pp. 1-35.

36. Estrada, J. Mean-Semivariance Behavior (II): The D-CAPM. SSRN Electron. J. 2002. [CrossRef]

37. Bawa, V.S.; Lindenberg, E.B. Capital market equilibrium in a mean-lower partial moment framework. J. Financ. Econ. 1977, 5, 189-200. [CrossRef]

38. Harlow, W.V.; Rao, R.K.S. Asset Pricing in a Generalized Mean-Lower Partial Moment Framework: Theory and Evidence. J. Financ. Quant. Anal. 1989, 24, 285. [CrossRef]

39. Pedersen, C.S.; Hwang, S. Does downside beta matter in asset pricing? Appl. Financ. Econ. 2007, 17, 961-978. [CrossRef]

40. Harvey, C.R.; Siddique, A. Conditional Skewness in Asset Pricing Tests. J. Financ. 2000, 55, $1263-1295$. [CrossRef]

41. Kraus, A.; Litzenberger, R.H. Skewness Preference and the Valuation of Risk Assets. J. Financ. 1976, $31,1085$. [CrossRef]

42. Kienberger, S.; Hagenlocher, M. Spatial-explicit modeling of social vulnerability to malaria in East Africa. Int. J. Health Geogr. 2014, 13, 29. [CrossRef] [PubMed]

43. Ren, C.; Zhai, G.; Zhou, S.; Chen, W.; Li, S. A comprehensive assessment and spatial analysis of vulnerability of China's provincial economies. Sustainability 2018, 10, 1261. [CrossRef]

44. Pástor, L'; Stambaugh, R.F. Liquidity Risk and Expected Stock Returns. J. Polit. Econ. 2003, 111, $642-685$. [CrossRef]

45. Newey, W.K.; West, K.D. A Simple, Positive-Definite, Heteroskedasticity and Autocorrelation Consistent Covariance Matrix. Econometrica 1987, 55, 703-708. [CrossRef]

46. Hwang, S.; Pedersen, C.S. Best Practice Risk Measurement in Emerging Markets: Empirical Test of Asymmetric Alternatives to CAPM; Working Paper; Cass Business School: London, UK, 2002.

47. Fama, E.F.; French, K.R. The Cross-Section of Expected Stock Returns. J. Financ. 1992, 47, 427-465. [CrossRef]

48. Jegadeesh, N.; Titman, S. Returns to buying winners and selling losers: Implications for stock market efficiency. J. Financ. 1993, 48, 65-91. [CrossRef]

49. Harvey, C.R. Predictable risk and returns in emerging markets. Rev. Financ. Stud. 1995, 8, 773-816. [CrossRef] 
50. Erb, C.; Harvey, C.; Viskanta, T. Expected returns and volatility in 135 countries. J. Portf. Manag. 1996, 46-58. [CrossRef]

51. Bekaert, G.; Erb, C.B.; Harvey, C.R.; Viskanta, T.E. What matters for emerging equity market investments. Emerg. Mark. Q. 1997, 1, 17-46.

52. Botosan, C.A.; Plumlee, M.A.; Wen, H. The Relation between Expected Returns, Realized Returns, and Firm Risk Characteristics. Contemp. Account. Res. 2011, 28, 1085-1122. [CrossRef]

53. Guay, W.; Kothari, S.; Shu, S. Properties of implied cost of capital using analysts' forecasts. Aust. J. Manag. 2011, 36, 125-149. [CrossRef]

54. Easton, P.D.; Monahan, S.J. An Evaluation of Accounting-Based Measures of Expected Returns. Account. Rev. 2005, 80, 501-538. [CrossRef]

55. Botosan, C.A.; Plumlee, M.A. Assessing Alternative Proxies for the Expected Risk Premium. Account. Rev. 2005, 80, 21-53. [CrossRef]

56. Fama, E.F.; French, K.R. Common risk factors in the returns on stocks and bonds. J. Financ. Econ. 1993, 33, 3-56. [CrossRef]

(C) 2018 by the authors. Licensee MDPI, Basel, Switzerland. This article is an open access article distributed under the terms and conditions of the Creative Commons Attribution (CC BY) license (http:/ / creativecommons.org/licenses/by/4.0/). 